Trinity University

Digital Commons@ Trinity

Library Faculty Research

Coates Library

2014

\title{
The Role of Faculty Autonomy in a Course- Integrated Information Literacy Program
}

Anne Jumonville

TrinityUniversity, ajumonvi@trinity.edu

Follow this and additional works at: https://digitalcommons.trinity.edu/lib_faculty

Part of the Library and Information Science Commons

\section{Repository Citation}

Jumonville, A. (2014). The role of faculty autonomy in a course-integrated information literacy program. Reference Services Review, 42(4), 536-551. doi: 10.1108/RSR-07-2014-0020

This Article is brought to you for free and open access by the Coates Library at Digital Commons @ Trinity. It has been accepted for inclusion in Library Faculty Research by an authorized administrator of Digital Commons @ Trinity. For more information, please contact jcostanz@trinity.edu. 
RSR

42,4

536

Received 2 July 2014

Revised 8 September 2014

9 September 2014

10 September 2014
Accepted 10 September 2014

\section{The role of faculty autonomy in a course-integrated information literacy program}

\author{
Anne Jumonville \\ Library, Trinity University, San Antonio, Texas, USA
}

\begin{abstract}
Purpose - The purpose of this paper is to explore the significance of faculty autonomy in sustaining a successful information literacy program.

Design/methodology/approach - Faculty members were given the opportunity to create courses that integrated and assessed information literacy as part of a course grant program associated with an institutional assessment mandate. This case study analyzes course grant proposals, course assessment methods and results. It also presents results of a follow-up survey of faculty participants to see if they continued to integrate information literacy in other courses. Results are situated in the context of self-determination theory to better understand the role of autonomy in faculty motivation and participation in an assessment program.

Findings - Defining and integrating information literacy themselves allowed faculty to align information literacy with their own course goals. Supporting faculty in choosing their own assessment methods for these integrations also provided program administrators with new information about faculty members' teaching and learning practices and values. Results of a follow-up study confirmed that faculty continued to integrate information literacy in their courses of their own accord, underscoring the importance of an autonomy-supportive program structure.

Originality/value - This paper provides evidence for information literacy advocates that faculty autonomy can be a strength, not an obstacle. It demonstrates ways to incorporate and allow for autonomy within program constraints and introduces librarians to self-determination theory, a way of thinking about motivation that can help librarians pursue more effective collaborations with faculty.
\end{abstract}

Keywords Information literacy, Motivation, Assessment, Faculty autonomy, Self-determination theory

Paper type Case study

\section{Introduction}

Academic faculty members exert a great deal of control and self-determination in relation to their teaching, their research and their other activities as college and university professors. As subject or disciplinary authorities and experts, they are selected by their institutions to help develop and guide the curricula related to their specialized areas of study. As librarians, we often partner with faculties who have strong ideas about the way research skills should be taught and assessed; likewise, we may work with those who defer to our expertise. In either case, it is often the teacher who will make the decision about the ways that information literacy learning is integrated

Reference Services Review

Vol. 42 No. 4, 2014

pp. 536-551

Emerald Group Publishing Limited 0090-7324

DOI 10.1108/RSR-07-2014-0020
(C) Anne Jumonville, 2014

Thanks to Benjamin R. Harris and Alexandra Gallin-Parisi for their feedback and support during the research and writing process. 
into their courses. As information literacy advocates have often aspired to influence or shape curriculum and the assessment of research skills development, it can be tempting to view faculty autonomy as merely an obstacle to overcome. Yet, at Trinity University in San Antonio, Texas, leveraging faculty autonomy and motivation propelled an Information Literacy Quality Enhancement Plan (QEP) from initial success to a lasting source of faculty engagement.

This case study will describe how faculty found their own ways to integrate and assess information literacy in new and revised courses within the constraints of a mandated assessment program. It will also describe the results of a follow-up survey that confirm the ongoing impact of the information literacy program beyond its groundbreaking early years. Finally, to extrapolate lessons learned, the results of this case study will be situated in the context of self-determination theory (SDT) to ground conversations about librarian - faculty collaboration and faculty engagement in a deeper understanding of motivational theory.

\section{Literature review}

Librarians have been keenly interested in the experiences, attitudes and collaborative potential of non-librarian faculty with regards to students' information literacy development, especially in regards to course-integrated information literacy learning. For their part, faculty members are often dissatisfied with students' information literacy abilities, though they may not always agree with librarians about the best ways to improve those abilities (Bury, 2011; DaCosta, 2010; Dubicki, 2013; Saunders, 2012). Although some librarians have found the attitudes and values of teaching faculty "barriers" to effective information literacy program implementation (Saunders, 2009), a wealth of case studies have reported successful collaborations between librarians and faculty to improve student information literacy learning (Bluemle et al., 2013; Johnson et al., 2003; Ostrow, 2010; Winterman et al., 2011; for a thorough review of faculty-librarian collaborations for composition courses between 1998-2007, see Mounce, 2009).

While the literature on the importance of collaboration in information literacy teaching and programming is plentiful, research in library information science (LIS) about what motivates faculty to collaborate with librarians is less common. This is not to say LIS practitioners and researchers have been unaware of the importance of motivation. In many ways, we have addressed questions of motivation implicitly. Patricia Iannuzzi called for librarians to reframe their thinking from "how can the information literacy agenda be integrated into this initiative", to "how can the information literacy agenda help this initiative succeed", suggesting a relocation of our own motivations (Iannuzzi, 1998, p. 99). Laura Saunders considered the motivating potential of institutional accreditation guidelines that include information literacy, concluding that "librarians should recognize and take advantage of attention from quarters such as accrediting organizations, which could potentially be much more convincing to administrators and faculty members" (Saunders, 2008, p. 312). In examining the motivations of faculty members to address students' research skill development themselves, Laurie McNamara Morrison found that faculty were motivated by their own pedagogical goals, perceived inadequacies in student ability, as well as their position as academics, interested in drawing others into their field of study (Morrison, 2007).

\section{Course-integrated information literacy program}


RSR

42,4

538
While the work summarized above can help librarians to better position ourselves in relation to faculty, administrators and a broader information literacy agenda, it does not necessarily illuminate deeply engrained elements of academic faculty cultures that also come into play when collaborating or developing programs that require faculty engagement to succeed. One element that has rarely been discussed in relation to library programs is the impact of faculty autonomy. In a major 1995 study on faculty motivation, presenting a comprehensive analysis across institution types and the traditional division of faculty work (i.e. research, teaching and service), Robert $\mathrm{T}$. Blackburn and Janet H. Lawrence found that the variable termed "self-efficacy" as an indicator of motivation "was significant in 26 instances at one time or another in every institutional type and academic discipline" (Blackburn and Lawrence, 1995, p. 281). Self-efficacy represents a sense of control (autonomy) and competence in one's goals and actions. While "allowing" or encouraging faculty to take greater ownership over information literacy has received positive attention in LIS (Cowan, 2014; Miller, 2010), few information literacy programs have attempted to make explicit use of faculty autonomy as a starting point (see Sajdak, 2012 for an exception).

Comprehensive motivational theories such as SDT, long-used in the field of education, have great potential to help librarians not only frame but also to ensure the continued success of major initiatives and programs that rely on faculty adoption and ownership. SDT seeks to explain the impact external factors have on intrinsic motivation, as well as the process by which extrinsic motivations can be integrated and internalized (Deci, 1975). Edward L. Deci and Richard M. Ryan, SDT's foundational theorists, have found in numerous studies that when an environment supports the psychological needs for autonomy (volition/freedom to act according to one's own desires), competence (effectiveness) and relatedness (feeling connected to others), people are more likely and able to internalize externally derived ideas, values and practices (Deci and Ryan, 1985; Deci et al., 1999; Ryan and Deci, 2000). This matters because, while externally motivating factors can still produce desirable outcomes, intrinsically motivated people "have more interest, excitement, and confidence, which in turn is manifest both as enhanced performance, persistence and creativity" (Ryan and Deci, 2000, p. 69). If external motivations can be internalized in ways that result in similar levels of engagement through support for autonomy, competence and relatedness, it is no surprise that managers, coaches, therapists and teachers have been quick to see the potential of SDT in applied settings (Gagné and Deci 2005; Reeve, 2002; Stone et al., 2009). Though Deci and Ryan do not posit that extrinsic motivations can "become" intrinsic, they do propose that the process of internalization occurs to varying degrees. In short, not all "extrinsic" motivational states are the same. They categorized these states as external regulation (motivated by a reward or punishment); introjection (motivation includes internal consequence, i.e. feeling guilty), identification (finding value in the action/behavior) and integration (valuing the activity/behavior becomes part of one's sense of self) (Ryan and Deci, 2000). A person in the latter stage who has integrated extrinsic motivations is considered by Deci and Ryan to be "self-determined" and capable of autonomous or self-regulated behavior to a similar extent as someone who is inherently interested in the task or activity (intrinsic motivation).

In her discussion of the potential role of SDT in implementing externally mandated assessment programs in higher education, Rosemary Sutton offered useful examples of these motivational states as they pertain to assessment of teaching and learning in 
particular. For example, in identifying with the motivation to assess student learning, a teacher might feel that "[Assessment] is an important component of this job, a job that I value"; in integration, "[Conducting assessment] reflects who I am and what I value" (Sutton, 2005, p. 4). Importantly, SDT does not posit these stages as part of an inevitable progression, from external to integrated, but rather it identifies them as natural and active processes through which people negotiate and adapt to their environments (Ryan and Deci, 2000). The distinctions between the four levels are useful in understanding the different impacts of a particular level of motivation on the experience and quality of the action taken as a result; motivations at the level of identified and integrated function closer to intrinsic motivations, leading to greater satisfaction, performance and autonomous sustainability (Stone et al., 2009).

Most research on the use of SDT in educational settings has focused on understanding how students benefit from autonomous or intrinsic motivation and what it looks like for teachers to support student autonomy. Since the late 1970s, studies have consistently found that students who are autonomously motivated and whose teachers support their autonomy perform better (Reeve, 2002). In studying elements of faculty and teacher practices, recently, Lechuga and Lechuga used SDT to understand faculty motivations around their own research and scholarly practices (Lechuga and Lechuga, 2012), and Th. J. Ten Cate $e$ al. published a guide on how to use the insights of SDT in medical education (Ten Cate et al., 2011). There has also been some attention to SDT in regard to broader issues of school reform (Deci, 2009), and outside the educational sphere, to workplaces generally (for example, see Baard, Deci and Ryan, 2004; Stone et al., 2009). Ultimately, whether focused on the benefits to students or benefits to teachers, SDT offers librarians an alternate lens for understanding faculty motivation and encouraging faculty involvement in information literacy programming. In particular, a deeper understanding of the varying levels and effects of motivational states could provide librarians with new ways to approach collaboration with teaching faculty in the context of course-integrated information literacy.

\section{Context}

Trinity University is a private liberal arts university in the southern USA with 2,500 students (2,300 undergraduates), and in Trinity University 2008 it selected information literacy as the theme for its five-year QEP as part of the accreditation process for the Southern Association of Colleges and Schools (Expanding Horizons: Using Information in the 21st Century, 2008). The plan introduced a modified version of the ACRL Information Literacy Competency Standards for Higher Education (2000) with five discrete student learning goals: Access, Understand, Evaluate, Use Ethically and Create, referred to on campus and in this article as "the information literacy goals". As a core component of the program, faculty were encouraged to integrate information literacy into courses at all levels of the curriculum by revising existing courses and developing new courses through a course grant program. Grant applicants were asked to describe the incorporation of information literacy goals into course design and philosophy, assignments, impact on student learning and proposed evaluation criteria (exact course grant application questions are available on the program Web site, see Notes[1]). To support this work, the University offered faculty a $\$ 500$ grant to revise a course or a $\$ 1,000$ grant to create a new course in which information literacy played a central role (to be sure, the implications of offering a financial incentive will be addressed later on).
Course-integrated information literacy program

539 
RSR

42,4

540

While this article will focus on the role of faculty choices in the course grant program how they integrated, assessed and followed up on information literacy learning in their courses - some additional context about the other components of the QEP may be useful.

In addition to course grants, annual information literacy workshops for faculty introduced and contextualized the skills and knowledge implicit in information literacy. Workshops were organized by librarians but often featured teaching faculty in leading roles. Similar workshops for staff encouraged information literacy programming at the co-curricular level. Workshops for faculty often served as an entry point to the course grant process, though workshop attendance was not a requirement for receiving a grant. Grant recipients attended regular mid-semester check-ins with other grant recipients (symposia) that were open to all faculties as well. Librarians also played a crucial role throughout the QEP, meeting with faculty in to encourage grant applications and work one-on-one to develop assignments, courses and assessments that would meet grant requirements. Three librarians also served on the committee that awarded grants, along with a rotating group of faculty, staff and administrators. In addition, librarians usually conducted instruction sessions for courses that received grants to support students' information literacy development, building on already established instructional relationships with faculty. Readers interested in these and other elements of Trinity's information literacy QEP are encouraged to consult previously published works, including a more detailed introduction to the development of the QEP goals, structure and a discussion of gaining campus support (Millet et al. 2009), to strategies for integrating information literacy in assignments (Jumonville, 2014) and to the use of collaboratively developed rubrics for assessment (Oakleaf et al. 2011). Assessments of student information literacy development and evidence of overall program success are also available through Trinity's Institutional Repository[2].

In the course grant program, which is the focus of this analysis, 86 courses received course revision grants and 54 courses received new course grants, for a total of 140 grants awarded between 2008 and 2013. The majority of grants were awarded to courses at the 1000 level (58 courses) and 3000 level (49 courses). Fourteen courses received grants at the 2000 level, 16 at the 4000 level, and 3 at the 5000 level (graduate). This article will focus on grants at the 1000-4000 levels to provide a picture of the impact on faculty teaching undergraduate courses.

Overall, the program engaged approximately 36 per cent of the university faculty, for a total of 88 faculty members participating from 23 of the 24 departments across the campus. The program allowed faculty to participate more than once; in fact, 34 faculty members received two or more grants over the course of the program's five years. Forty-eight per cent of grant recipients held the rank of Assistant Professor at the time they applied for a course grant; 26 per cent Associate Professor; 14 per cent Professor; and 11 per cent Instructor/Term/Adjunct (percentages will not equal 100 due to rounding).

\section{Method}

The course grant program successfully engaged faculty in revising and developing courses to incorporate information literacy. But how and why had faculty integrated information literacy, and were those integrations sustainable over time? To investigate these questions, each successful grant application document and accompanying post-course assessment was analyzed and then compiled in a spreadsheet of all grants 
with the following information: course details, information literacy goals addressed, descriptions of those goals in applicant's own words, applicants' explanations of their reasons for incorporating information literacy and results of the course. After compiling this information for each grant and examining the grants collectively, each grant was re-examined to confirm patterns and themes.

Naturally, the presence of financial incentives makes it challenging to accurately situate other motivations for participation. To be clear, the presence of a financial incentive is a limitation of this study. However, as faculty also gave a variety of other rationales to explain their choice to revise or develop a new course for the program, it seemed that there might be room for multiple motivations. Also, most importantly, as there was no financial incentive to keep integrating information literacy beyond the initial semester for which a course grant was received, examining post-grant activity is crucial to understanding longer-term, and potentially more autonomous, faculty motivation and action. As such, a follow-up survey was designed in collaboration with the library's then Information Literacy Coordinator and the Trinity Office of Institutional Research and administered the semester after the last course grants were awarded. The survey focused on the continued integration of information literacy in either the course originally receiving the grant or in recipients' other courses. The full survey, including questions as worded and responses, is available through Trinity's Institutional Repository[3]. The survey had a high response rate of 83 per cent of original grant recipients, adding value to its findings. Per campus policy, none of the assessment instruments described above required IRB approval, as they were conducted as part of the overall institutional QEP assessment process.

\section{Analysis}

Integrations of information literacy in course grant applications. Courses were not pre-selected for information literacy integration. While the QEP laid an intended scaffolding of specific information literacy goals by course level, individual faculty members were the ones to choose whether to participate in the program, which courses they wanted to revise or develop to integrate information literacy and even which information literacy goals they wanted to incorporate. Thus, while the program emphasized three particular information literacy learning goals for first-year courses accessing information effectively ("Access"), understanding the varieties of information sources ("Understand") and using information ethically ("Use Ethically") - course grants were awarded to first-year courses for other information literacy goals, too. As a result, by encouraging the intended structure while allowing for flexibility, first-year course grants actually exceeded the intended information literacy integration: of the 30 course grants awarded to courses offered to first-year students, 29 targeted "Access", 28 "Understand" and 24 "Use Ethically" (keeping in mind individual courses could, and usually did, target multiple goals). Yet, 20 first-year course grants also asked students to engage in the process of evaluating information sources ("Evaluate"), and 11 gave students opportunities to create significant information products ("Create") - both goals the Information Literacy QEP originally intended to address in more advanced levels. Thus, while the majority of courses addressed the intended goals, many went beyond them and added additional information literacy components as individual faculty saw fit.

\section{Course-integrated information literacy program}


RSR

42,4

542

A similar pattern played out for grants awarded to courses beyond the first-year level. For Common Curriculum courses (general education requirements) and courses in the major, the QEP proposed a continued emphasis on "Access" and "Use Ethically", but added "Evaluate" as a third goal. Even so, a majority of faculty applying for Common Curriculum and in-the-major course grants continued to address "Understand" as well, and 45 also asked students to meet the senior-level goal of "Create." Clearly, faculty continued to target and assess goals that fit not only their course aims but their own understanding of information literacy as well. Admittedly, some of this programmatic flexibility served strategic ends administratively - to maintain program participation and momentum - but it also allowed for a deeper understanding of how faculty not only adopted information literacy but adapted it, conceptually, to align with more personally resonant motivators.

In many cases, grant recipients' sensibilities about the learning connected to information literacy goals underscored a more holistic - and at times more ambitious approach than the course grant program originally envisioned. In their applications, faculty spoke of information literacy in both broad and contextualized terms. In terms of the former, one described the integration of information literacy as wanting students to be able to "face a research problem", or "develop understanding regarding the nature of information sources and how they vary in authority and readership". One instructor of a first-year course saw information literacy as a pedagogy that enabled "students" transition into college through assignments that [teach] them to academically critique what they already watch, listen to or read in their leisure time", while another hoped that information literacy assignments would propel students to "develop the skills needed to be a good participant in intellectual discussion". Some course grants did maintain more conventional expressions information literacy goals, such as "learn to identify and use appropriate sources" and "reflect upon the relevance and value of those sources for their project". Whether information literacy goals were expressed broadly or more narrowly, in articulating the role of information literacy in their own words, faculty made connections between information literacy and pedagogical goals they already valued and sought to implement. As was mentioned earlier, the importance of personally valuing a goal or practice - and not just engaging with it to meet external requirements exemplifies a more internalized and sustainable level of motivation, a state of identification with the goal or practice.

In addition to research and information-seeking outcomes, faculty continued making connections, placing information literacy goals in relation to other desirable course or discipline-specific outcomes. For example, several teachers in literature courses used information literacy goals to underscore the process of literary canon formation. A business course assignment required students to "analyze financial information released by different players in the financial market", and others used information literacy assignments to encourage students to reflect more deeply on course-related internship experiences, or used information literacy to leverage other literacies, such as science, statistical and media literacy. In analyzing and categorizing the range of faculty intentions behind integrating information literacy, four general themes emerged, as illustrated in Table I.

There were many course grant applications that touched on more than one reason or rationale (hence the total in Table I exceeds the total number of grants awarded, 140). For example, 19 course grant applicants hoped information literacy would help to 
"prepare students for future college coursework" and also "prepare students for professional and personal lives beyond Trinity University"; similarly, 14 wanted the incorporation of information literacy to "acquaint students with discipline-specific research practices" while also "preparing them for professional/personal lives beyond Trinity University". Another 15 thought it could "address a previously observed gap in student learning" while also "preparing students for professional and personal lives beyond Trinity University". Though certainly one might attribute the ambitious vision of grant recipients as application rhetoric intended to secure the financial reward associated with the grant, it is useful to note that of the rationales listed here, "preparing students for future college coursework", "addressing previously observed gaps in student learning", and "acquainting students with discipline-specific research practices” also confirm McNamara Morrison's 2007 findings regarding faculty motivation for teaching research skills (i.e. other pedagogical goals and/or a desire to bring students into an academic community of practice). Thus, an analysis of the course grant applications suggests that the way faculty at Trinity University chose to conceptualize information literacy and, as a consequence, how they integrated those understandings into their courses also offers a window into part of what motivated them to do so in the first place. In other words, supporting a range of information literacy understandings and allowing for flexibility in selecting information literacy goals (Access, Understand, Evaluate and Use Ethically create) and concepts allowed faculty a degree of autonomy as program participants and deepened the connections between information literacy and other pedagogical aims. Even as they may have been originally motivated to participate in the program by the financial incentive, they also made clear connections to other pedagogical motivators.

\section{Analysis of faculty assessment practices and results}

Just as faculty members were given a considerable amount of freedom in selecting the information literacy learning goals that would be integrated into their course plans and assignments, they maintained a similar level of autonomy in the development of assessment measures. This does not mean that they did not receive support or guidance. Much of the groundwork in developing suggested practices to assess information literacy learning, especially in the use of rubrics and developing assessment criteria, occurred in librarian-led workshops, in which the importance of collegial support (an example of relatedness, in SDT) played a crucial role. A report and analysis of the workshops, librarian support and peer guidance has not been completed at this time, but would be a worthy project for future study. For the purposes of this article though, it is useful to note that when faculty members applied for information literacy course grants, they were free to choose the method of assessment that best fit their course and assignments. Unsurprisingly, this resulted in a range of assessment and evaluation

Reasons for including information literacy outcomes

Prepare students for future college coursework

Address previously observed gaps in student learning

Acquaint students with discipline-specific research practices

Prepare students for professional and personal lives beyond (institution name)

\section{Course-integrated information literacy program}

543 


\section{RSR \\ 42,4}

\section{4}

\section{Figure 1.}

Assessment methods selected by grant applicants to measure IL learning

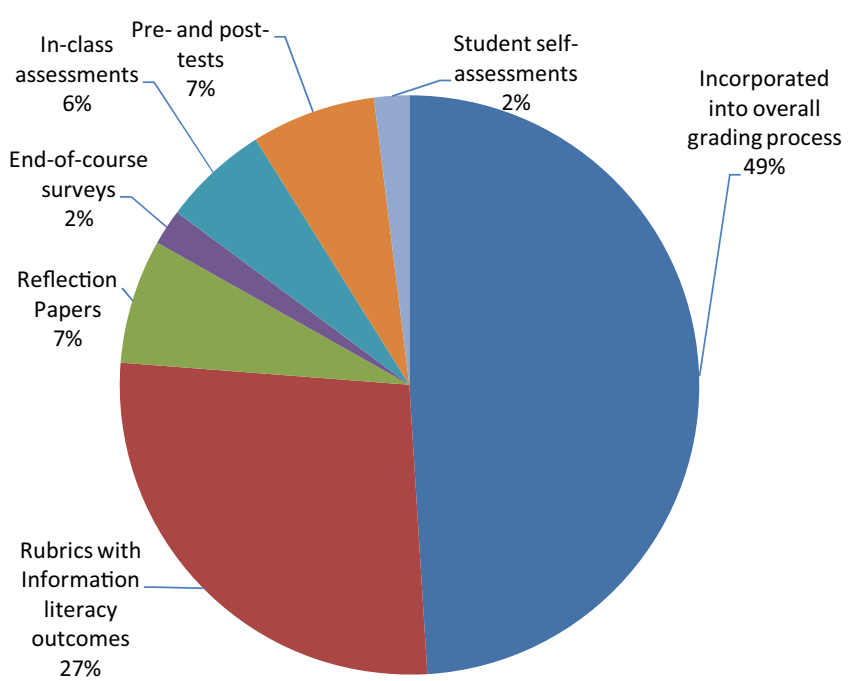

types, as illustrated in Figure 1. While this variety in assessment measures creates challenges for those hoping to aggregate assessment data, it does show the kinds of directions teachers will take when they are given the freedom to determine assessment measures to gauge information literacy learning.

While quantitative assessments of students' information literacy learning (whether through the use of rubrics, portfolios and other methods) are useful and likely the type of assessment valued by most institutional measures, course grant recipients supplied even richer assessment data in the form of post-course assessment narratives. Of the 140 participants, 107 submitted assessment narratives that helped clarify the impact of the program on faculty participants and what they thought about students' information literacy development. As the value of the narrative became apparent over the course of the QEP program, it was increasingly encouraged by the grant-awarding (and assessment-collecting) committee, but a particular structure was never required. The assessment narratives, along with any other assessment information collected, was turned into the same committee awarding the grant. As such, there certainly may have been a desire to provide a positive report. However, on the whole, the narratives were careful in their claims. Some explained some of the discrepancies between information literacy achievements, such as students' more successful abilities to access information versus their less-developed abilities to evaluate it or create new knowledge with it.

Similarly, many faculty used the narrative to confirm the positive impact of information literacy while also reflecting critically on the experience of teaching the new or revised course, or to qualify claims about student learning. For example, as one grant recipient wrote:

The papers were of a higher standard, which certainly partly attributable to the better sources the students found. I should also note that this was an exceptional group of students - their average grades were higher than other upper-level classes I have had on all kinds of assignments. 
Though the higher quality of papers may not be completely due to information literacy integration in that particular course, as that faculty member noted, it was certainly a factor, and one supported by other grant reports. In fact, 63 assessment narratives commented on the high quality of student work as a result of integrating information literacy.

Assessment narratives were nuanced in other ways. Fifty-three noted that the incorporation of basic levels of information literacy actually revealed the need for more advanced skills. As one wrote:

In many cases, what I found was that it is very difficult for students to come up with their own ideas and/or interpretation; they can find information and summarize it, but they have a hard time analyzing it meaningfully.

Others focused their assessment on the success or failure of particular assignments; one grant recipient described a bibliography assignment that fell "flat" and did not suggest much engagement, but a video presentation that "proved to be an excellent assignment for using what we had been studying in the course in order to construct something original and intellectually valuable."

In addition to observing the quality of student work and noticing areas in which students still lacked desired abilities, 72 of the assessment narratives also made clear connections between incorporating information literacy and improvements in other areas of the course, such as increased engagement in class discussions or with course material. Grant recipients noted a variety of areas in which such connections were evident in their minds: one noted that "making active reading and searching for texts a part of the writing process from the beginning of semester made for better creative work", while another wrote:

I think by being aware of how much academic authors diverge on a given topic, students are gaining greater self-consciousness about their own interests and the ability to pursue different angles.

Even as these types of reflective assessments still indicate faculty members' perceptions of student learning and growth, not more direct assessments of student learning, they indicate connections grant recipients made between information literacy and other, possibly more personally significant pedagogical motivations.

The assessment narratives created by faculty members suggest that encouraging faculty choice in the selection of information literacy learning outcomes for a particular class, the independent (if guided) integration of information literacy learning into the course curriculum and the selection of appropriate class-specific assessment measures were all important to the successful integration and enhancement of information literacy learning in these classes. Further, encouraging faculty autonomy related to the integration and assessment of information literacy seemed to encourage greater reflection on teaching and course design generally. Grant recipients proved thoughtful observers of the impact of course change at a variety of levels; while this did not always result in tidy rubric scores, it did provide evidence of the impact of information literacy not only on student achievement, but also on faculty perception of students' course experience and on their own experiences as instructors and course designers. Thus, supporting autonomy allowed faculty to align information literacy with other powerful pedagogical motivations, broadened the scope of information literacy in the curriculum and enhanced the range and impact of assessment results.

\section{Course-integrated information literacy program}


RSR

42,4

546
Analysis of ongoing impact: A follow-up survey

So far, this article has described ways that the faculty members at Trinity University exercised autonomy in the ways that a course addressed and assessed information literacy learning as part of our course grant program. At this point, an obvious question remains: what happens to the integration of information literacy when the course grant funding runs out and faculty, likely originally motivated at least in part by the possibility of a financial incentive, are left to their own devices and motivations?

To investigate, grant recipients were surveyed in the semester following the end of the program, though for some it may have been several semesters since they received a course grant. The survey focused on whether and how recipients continued to incorporate information literacy in their courses. The results confirmed that the course grant program led to ongoing attention to students' information literacy learning: 90 per cent of those surveyed said that they continued to incorporate information literacy outcomes in the course for which they originally received a grant. Grant recipients were also asked if they made additional changes to the course's instruction, assignments, syllabus, etc. during subsequent semesters. More than half had made minor changes in the way they taught (67 per cent) or in their syllabus (57 per cent). Forty-four per cent made minor changes to assignments and 48 per cent said they made substantial changes to assignments. The high percentage that continued making changes also makes sense given the fact that many may have been trying out a new assignment, or even new course, for the first time. Continued revision, especially after the first implementation of a course or assignment, is a common practice not limited to information literacy integration in particular.

Even if faculty may have been motivated to maintain early changes merely due to inertia - why change the course again if it was working well - what may be more significant is that 71 per cent per cent said they made changes in other courses to incorporate information literacy - courses for which they never received a grant. This suggests that grant recipients may have been motivated not only to continue building on changes to the original grant-receiving course but also saw reason to transfer successful assignments and strategies to other courses as well. Of the 71 per cent who made changes in other courses, 85 per cent said those changes included incorporating the goal of evaluating information; 81 per cent understanding information sources; 75 per cent accessing information effectively; 71 per cent synthesizing information to create new knowledge products; and 69 per cent using information ethically. In sum, faculty members integrated all five of the information literacy goals across their courses and by their own choice. Would this have happened had the integration of information literacy outcomes in courses receiving grants been determined by someone other than the faculty member? A strong argument can be made that by "owning" the information literacy-related revisions and additions to those classes receiving course grants, faculty members were better able to see the potential value of these learning outcomes and teaching strategies in other contexts. There are a range of possible other factors upon which we could speculate as to why that was the case. Ultimately, though, what's clear is that faculty members receiving grants were motivated enough to continue integrating and assessing their students' information literacy learning in courses that were not associated with the QEP or the course grants program. 


\section{Discussion}

Before moving into a discussion of these results in a theoretical context, a summary of the previous results and analyses may be useful. Working within the context of a structured institutionally mandated information literacy QEP, faculty grant recipients chose information literacy goals that fit within their own pedagogical frameworks, and, in explaining the connections, also articulated their understanding of the role of information literacy in their courses, for themselves as instructors and for students as learners. Faculty chose and wrestled with methods for assessing those goals. They demonstrated students' abilities to meet information literacy outcomes, but also offered critical reflections on problems encountered, described extenuating factors that helped explained successes and failures, suggested next steps and confirmed the usefulness of information literacy as a prompt for course redesign. Finally, they indicated a strong willingness to sustain, of their own accord, the integration of information literacy into their other courses, post-grant. Alone, these results are worthy of public report. However, is it possible to extend their value by situating such successful information literacy integration in a discussion of motivational theory? The discussion to follow will attempt to do so. A SDT-based analysis of this program may invite further reflection on the nature of motivation as it pertains to working with faculty, collaborating on teaching and program administration.

According to SDT research, many elements of program administration impede individual autonomy and intrinsic motivation for a task, such as oversight, evaluation (or assessment!), deadlines and even, in some cases, the presence of rewards (Deci and Moller, 2005). Yet, administrative requirements are often a necessary component of any information literacy program, particularly one that is closely associated with accreditation-required assessments. Then, how to adapt administrative requirements to encourage the type of motivational states associated with deeper satisfaction and better performance (Stone et al., 2009) and more sustainable, meaningful, and competent work (Gagné and Deci, 2005)?

At Trinity, the negative impact of administrative requirements was partially mitigated by encouraging faculty members to connect information literacy to existing learning goals and disciplinary values and to choose the elements of information literacy that best fit those goals and values. While the idea of connecting the language of information literacy to more "native" disciplinary contexts is hardly news in LIS, understanding why that matters in terms of a theoretical understanding of motivation has not been emphasized as much. Faculty at Trinity University could participate in the QEP based on any number of motivations, from the purely external (financial reward) to more integrated (valuing the integration and assessment of information literacy for its own sake) - or, quite likely, a combination of motivations. Whatever level of motivation led to the initial choice to participate, the use of small mechanisms, such as asking faculty to describe the connection between information literacy and their course philosophy in the grant application, or encouraging a range of assessment strategies, set the stage for deeper connections and more integrated motivations.

In addition, the chance to work out significant challenges by way of the course grant - in this case, problems with previous student learning and the challenge of creating new assignments and assessments - may also represent the type of "optimal challenge" suggested by Stone et al. (2009) as a means for supporting autonomy and developing competence. The opportunity to not only work out those challenges alone,
Course-integrated information literacy program

547 
RSR

42,4

548

but to do so with peers, hints at another component of SDT introduced earlier - the importance of relatedness. The chance to talk and connect with colleagues at workshops about teaching and learning generally was, in the early years of the QEP, one of its major attractions for faculty. "Teach the teacher" approaches have been suggested in LIS literature as a way to encourage information literacy development (for example, see Fister, 2009), though again, not typically in terms of how they affect motivation through supporting autonomy, relatedness or competence specifically. Though this article has been primarily concerned with the role of autonomy in information literacy program development, the importance of relatedness, especially in the form of collegial support, should not be underestimated and, as mentioned earlier, deserves further attention. Linking information literacy with opportunities that met other faculty needs, such as the need to collectively address commonly observed "problems" with student writing and research likely allowed the QEP to leverage a more sustainable and self-determined level of faculty motivation.

Supporting autonomy in course design also helped faculty develop increased competence in their understanding and assessment of course achievements. The range of options for assessment also echoes the recommendations of Stone, Deci, and Ryan, who recommend offering choices within structures that may still require certain constraints (Deci and Ryan, 2000, p. 81) to support individual autonomy. Of course, from an administrative perspective, allowing for not only multiple types of assessment data but multiple understandings of what assessment is led to a richer but certainly much more complicated set of results. The analysis of this program illustrates that point; the impact of what faculty accomplished at Trinity University in their course redesigns simply cannot be aggregated cleanly. Of the 140 grant applications, many faculty assessed gains in individual information literacy goals; some found evidence of high-quality work as a result of including information literacy, but also attributed these to multiple factors; still others described their perception of student experiences, while other colleagues focused on changes to make for the next iteration of the course. Many examined the results of their course in more than one of these ways.

At a time when institutions - especially libraries - feel even more pressured to articulate and defend our value in the clearest possible terms, this is not a neat and tidy assessment story. Yet, had Trinity limited the ways in which faculty could participate and assess the impact of that participation, not only would it have limited faculty autonomy and engagement in the assessment process, but unintended, positive impacts of the information literacy program may not have come to light, such as the development of new and successful faculty teaching practices and the ability of information literacy course revisions to enhance faculty members' other, perhaps more personally motivating, course goals. It may be that to maintain a balance between information literacy as a measure of institutional success, and also as a means for tapping into a faculty member's individual motivations and desired course outcomes, it is crucial to establish faculty autonomy as a component of program development and implementation. As was the case at Trinity University, such a move is critical not only to ensure stronger information literacy integration but also to help program administrators stay open to unexpected results and program evolutions. 


\section{Conclusion}

The case at Trinity University is unique in many ways. The size of the school, initial budget for course grants, timing of the program amidst other forces at work in the institution, quality of the faculty and students, strong existent relationships between librarians and non-librarian faculty and other factors all certainly contributed to the program's success. Yet, one major component of that success from the perspective of seeing the program completed is the degree to which faculty members were able to make choices within the confines of the program. These choices reveal ways of thinking that can help librarians understand how and why faculty members choose to integrate information literacy, what about that integration matters to them, and what they notice about student learning and their own teaching as a result. Supporting autonomy not only allowed program participants more ways to connect to and support the program, but enriched it from an administrative perspective. There will always be a range of motivations around new or existing educational initiatives; SDT helps to unpack the varieties of extrinsic motivation and ways in which people are more likely to internalized external values and priorities. Librarians in particular may benefit from theoretically rooted understandings of human motivation to better understand faculty values and develop more sustainable and engaging partnerships and programs.

\section{Notes}

1. QEP program Web site with course grant application questions: http://php.trinity.edu/qep/ info_lit/

2. Assessments of student information literacy learning and overall program results: http:// digitalcommons.trinity.edu/infolit_qep/

3. Trinity University QEP Grant Recipient Survey Results: http://digitalcommons. trinity.edu/infolit_qep/5/

\section{References}

Association of College and Research Libraries. (2000), Information Literacy Competency Standards for Higher Education, American Library Association, available at: www.ala.org/ acrl/standards/informationliteracycompetency (accessed 26 June 2014).

Baard, P.P., Deci, E.L. and Ryan, R.M. (2004), "Intrinsic need satisfaction: a motivational basis of performance and well-being in two work settings", Lournal of Applied Social Psychology, Vol. 34 No. 10, pp. 2045-2068.

Blackburn, R.T. and Lawrence, J.H. (1995), Faculty at work: Motivation, expectation, satisfaction, Johns Hopkins University Press, Baltimore, MD.

Bluemle, S.R., Makula, A.Y. and Rogal, M.W. (2013), "Learning by doing: performance assessment of information literacy across the first-year curriculum”, College \& Undergraduate Libraries, Vol. 20 No. 3, pp. 298-313.

Bury, S. (2011), "Faculty attitudes, perceptions and experiences of information literacy: a study across multiple disciplines at York University, Canada", Lournal of Information Literacy, Vol. 5 No. 1, pp. 45-64.

Cowan, S.M. (2014), "Information literacy: the battle we won that we lost?", Portal: Libraries \& The Academv, Vol. 14 No. 1, pp. 23-32.

DaCosta, J.W. (2010), "Is there an information literacy skills gap to be bridged? An examination of faculty perceptions and activities relating to information literacy in the United States and England", College \& Research Libraries, Vol. 71 No. 3, pp. 203-222.

\section{Course-integrated information literacy program}


RSR

42,4

550
Deci, E.L. (1975), Intrinsic Motivation, Plenum Press, New York, NY.

Deci, E.L. (2009), "Large-scale school reform as viewed from the self-determination theory perspective", Theory and Research in Education, Vol. 7 No. 2, pp. 244-253.

Deci, E.L., Koestner, R. and Ryan, R.M. (1999), "A meta-analytic review of experiments examining the effects of extrinsic rewards on intrinsic motivation”, Psvchological Bulletin, Vol. 125 No. 6, pp. 627-668.

Deci, E.L. and Moller, A.C. (2005), "The concept of competence: a starting place for understanding intrinsic motivation and self-determined extrinsic motivation", in Elliot, A.J. and Dweck, C.S. (Eds), Handbook of Competence and Motivation, Guilford, New York, NY, pp. 579-597.

Deci, E.L. and Ryan, R.M. (1985), Intrinsic motivation and self-determination in human behavior, Plenum Press, New York, NY.

Deci, E.L. and Ryan, R.M. (2000), “The 'what' and 'why' of goal pursuits: human needs and the self-determination of behavior”, Psychological Inquiry, Vol. 11 No. 4, pp. 227-268.

Dubicki, E. (2013), "Faculty perceptions of students' information literacy skills competencies", Lournal of Information Literacy, Vol. 7 No. 2, pp. 97-125.

Fister, B. (2009), "Fostering information literacy through faculty development", Library Issues: Briefings for Faculty and Administrators, Vol. 29 No. 4, pp. 1-4. available at: www.libraryissues.com/ (accessed 26 June 2014).

Gagné, M. and Deci, E.L. (2005), “Self-determination theory and work motivation”, Lournal of Organizational Behavior, Vol. 26 No. 4, pp. 331-362.

Iannuzzi, P. (1998), "Faculty development and information literacy: establishing campus partnerships", Reference Services Review, Vol. 26 Nos 3/4, pp. 97-116.

Johnson, C.M., McCord, S.K. and Walter, S. (2003), "Instructional outreach across the curriculum: enhancing the liaison role at a research university", Reference Librarian, Vol. 39 No. 82, pp. 19-37.

Jumonville, A. (2014), "The humanities in process, not crisis: information literacy as a means of low-stakes course innovation”, College and Research Libraries News, Vol. 75 No. 2, pp. 84-87.

Lechuga, V.M. and Lechuga, D.C. (2012), "Faculty motivation and scholarly work: self-determination and self-regulation perspectives", Journal of the Professoriate, Vol. 6 No. 2, pp. 59-97.

Miller, I.R. (2010), “Turning the tables: a faculty-centered approach to integrating information literacy", Reference Services Review, Vol. 38 No. 4, pp. 647-662.

Millet, M.S., Donald, J. and Wilson, D.W. (2009), "Information literacy across the curriculum: expanding horizons", College \& Undergraduate Libraries, Vol. 16 No. 2, pp. 180-193.

Morrison, L.M. (2007), "Faculty motivations: an exploratory study of motivational factors of faculty to assist with students' research skills development", Partnership: The Canadian Journal of Library \& Information Practice \& Research, Vol. 2 No. 2, pp. 1-20.

Mounce, M. (2009), “Academic librarian and English composition instructor collaboration: a selective annotated bibliography 1998-2007”, Reference Services Review, Vol. 37 No. 1, pp. 44-53.

Oakleaf, M., Millet, M.S. and Kraus, L. (2011), “All together now: getting faculty, administrators, and staff engaged in information literacy assessment", Portal: Libraries \& the Academv, Vol. 11 No. 3, pp. 831-852. 
Ostrow, M. (2010), "Faculty-librarian collaborations at the University of Texas: curricular collaboration, information literacy and the core freshmen curriculum", Texas Library Journal, Vol. 86 No. 4, pp. 138-139.

Reeve, J. (2002), "Self-determination theory applied to educational settings", in Deci, E.L. and Ryan, R.M. (Eds), Handbook of self-determination research, University of Rochester Press, Rochester, NY, pp. 183-203.

Ryan, R.M. and Deci, E.L. (2000), "Self-determination theory and the facilitation of intrinsic motivation, social development, and well-being", American Psvchologist, Vol. 55 No. 1, pp. 68-78.

Sajdak, B.T. (2012), "Let the faculty do it", College \& Research Libraries News, Vol. 73 No. 4, pp. 196-199.

Saunders, L. (2008), "Perspectives on accreditation and information literacy as reflected in the literature of library and information science”, Lournal of Academic Librarianship, Vol. 34 No. 4, pp. 305-313.

Saunders, L. (2009), "The future of information literacy in academic libraries: a delphi study", Portal: Libraries \& the Academv, Vol. 9 No. 1, pp. 99-114.

Saunders, L. (2012), "Faculty perspectives on information literacy as a student learning outcome", Iournal of Academic Librarianship, Vol. 38 No. 4, pp. 226-236.

Stone, D.N., Deci, E.L. and Ryan, R.M. (2009), "Beyond talk: creating autonomous motivation through self-determination theory", Journal of General Management, Vol. 34 No. 3, pp. $75-91$.

Sutton, R.E. (2005), "Assessment of student learning: moving from compliance to internalization”, Assessment Update, Vol. 17 No. 6, pp. 4-5.

Ten Cate, T.J., Kusurkar, R.A. and Williams, G.C. (2011), "How self-determination theory can assist our understanding of the teaching and learning processes in medical education. AMEE Guide No. 59", Medical Teacher, Vol. 33 No. 12, pp. 961-973.

Trinity University. (2008), Expanding Horizons: Using Information in the 21st Century, (prepared for the Southern Association of Colleges and Schools Commission on Colleges), available at: http://php.trinity.edu/qep/info_lit/ (accessed 26 June 2014).

Winterman, B., Donovan, C. and Slough, R. (2011), "Information literacy for multiple disciplines: toward a campus-wide integration model at Indiana University, Bloomington", Communications in Information Literacy, Vol. 5 No. 1, pp. 38-54.

\section{Further reading}

Roth, G., Assor, A., Kanat-Maymon, Y. and Kaplan, H. (2007), “Autonomous motivation for teaching: how self-determined teaching may lead to self-determined learning", Lournal of Educational Psychology, Vol. 99 No. 4, pp. 761-774.

\section{About the author}

Anne Jumonville is First-Year Experience Librarian and Assistant Professor at Trinity University. She holds an MS in Library and Information Science from University of Illinois at Urbana-Champaign. Anne Jumonville cab be contacted at: ajumonvi@trinity.edu

To purchase reprints of this article please e-mail: reprints@emeraldinsight.com Or visit our web site for further details: www.emeraldinsight.com/reprints 